\title{
Coxsackievirus infections in pregnant women with a parallel experimental model infection showing possible effects on course of pregnancy
}

\author{
L. Marosova, M. Sojka, J. Precechtelova, D. Stipalova, M. Badurova, \\ M. Borsanyiova, S. Bopegamage \\ ${ }^{1}$ Department of Virology, Slovak Medical University \\ 12, Limbova St., Bratislava, Slovak Republic, 83303 \\ lenka.marosova@szu.sk
}

\begin{abstract}
Aim of our work was firstly to determine the prevalence of anti-coxsackievirus antibodies during pregnancy. 217 serum samples were tested for antibodies by virus neutralization test against coxsackieviruses (CV) B1-B6, A7 and A9. The second aim was to investigate experimental transmission of virus to the fetus during pregnancy. Methods. Virus Neutralization Test, RT-PCR. Results. In the serological study, paired blood serum samples from 217 pregnant women were studied for antibodies against coxsackievirus serotypes (CVB1-CVB6, CVA7 and CVA9) in sera of pregnant women from selected areas of the Slovak Republic. Coxsackievirus B4 (CVB4) infection was most prevalent, followed by CVB3, CVA7, CVA9, CVB5, CVB2, CVB1 while coxsackievirus B6 (CVB6) was scarce. In 30 out of 217 cases (13.82\%) current infection was recorded. In the experimental murine study, in the second week of gravidity we observed presence of enteroviral RNA in the placenta and the intestine of the dead fetuses of the mice. Conclusions. Anti-CV antibodies were prevalent in the pregnant mothers indicating circulation of these viruses in the population. Current infection was shown in $13.82 \%$ of studied cases. Presence of virus RNA in the organs of the unborn fetuses in the experimental infection indicates the possibility of transfer of the coxsackievirus B4-E2 infection from mother to child during antenatal development.
\end{abstract}

Keywords: coxsackieviruses, pregnancy.

Introduction. Enteroviruses are distributed worldwide with the highest frequency in temperate climate. Their circulation increases during summer and early autumn [1]. Enterovirus infections are usually unapparent. They manifest broad spectrum of symptoms like mild nonspecific febrile illness or infection of upper respiratory tract. In some cases, particularly in newborns or immunodeficient patients, they may cause serious illnesses like aseptic meningitis, encephalitis and myocarditis, they may rarely give rise to serious newborn

(C) Institute of Molecular Biology and Genetics NAS of Ukraine, 2011 sepsis or paralytic poliomyelitis [2-4]. Enteroviruses also play a role in etiology of chronic illnesses, e. g. dilated cardiomyopathy and infections by these viruses may lead to development of type 1 diabetes (T1D) [5, 6]. These viruses may cause severe or fatal illnesses of newborns [7]. They have been detected in amniotic fluid, placenta and in tissue of the fetus [8]. These infections are linked to various congenital anomalies, stillborn fetuses or abortions [8].

Several experimental infection studies $[7,9,10]$ show effects of coxsackievirus infections on the course of gravidity, stillbirths, premature birth and higher 
Table 1

Prevalence of coxsackievirus serotypes in the studied cases

\begin{tabular}{c|c|c|c|c|c|c|c|c}
\hline Serotype & CVB1 & CVB2 & CVB3 & CVB4 & CVB5 & CVB6 & CVA7 & CVA9 \\
\hline +total & $62 / 217$ & $112 / 217$ & $148 / 217$ & $163 / 217$ & $126 / 217$ & $21 / 217$ & $144 / 217$ & $140 / 217$ \\
Percentage & 28.57 & 51.61 & 68.20 & 75.12 & 58.06 & 9.68 & 66.36 & 64.52 \\
\hline
\end{tabular}

$+/$ total $=$ number of positive sera/total number of sera studied.

death rate in female mice infected in later stages of the gravidity.

Our aim was to study the circulation of coxsackieviruses in pregnant women, and to investigate possibility of vertical transmission to the fetus by studying the presence of enteroviral RNA in the organs of the stillborn fetuses.

Material and methods. Measurement of antibody titers in pregnant women by the Virus Neutralization Test (VNT). Antibodies were detected and measured by the method described by [11]. Titers of antibodies against Coxsackieviruses: B1 (CVB1) strain Conn; B2 (CVB2) strain Ohio; B3 (CVB3) strain Nancy; B4 (CVB4) strain JVB; B5 (CVB5) strain Faulkner; B6 (CVB6) strain Schmitt (CVB6); A7 (CVA7) strain Parker, and A9 (CVA9) strain Griggs were determined in paired samples of sera from gravid women. Rise in antibody titers in the paired sera showed acute or recent infection.

A 4 fold $\log _{2}$ in paired samples increase of anticoxsackievirus antibodies by in sera was the marker of the current infection.

Detection of viral RNA in the dead fetuses of the experimental infected gravid mice.

CD-1 female mice were used for experimental infection. Permission for the animal work was obtained from the Ethics Committee of the Slovak Health University and the State Veterinary and Food Control Authority of the Slovak Republic. 9 pregnant mice were experimentally infected with CVB4 strain E2. Infectious dose of $1 \cdot 10^{7} \mathrm{TCID}_{50}$ in $0,5 \mathrm{ml}$ suspension of CVB4-E2 was given as described by [12] by oral gavage. Female gravid mice were infected during the three different gestational periods at day 4, 10 and 17 . We selected the pregnant mouse infected with virus in the second week gestation, which was lethargic and stopped showing gain in weight, and was sick to give birth. This mouse was sacrificed, dead fetuses were removed, and organs were studied for presence of RNA.
Detection of viral RNA. RNA Mini Kit («Invitrogen», USA) was used for isolation of RNA from prepared organ suspensions. SuperScript ${ }^{\mathrm{TM}}$ One-Step RTPCR with Platinum ${ }^{\circledR}$ Taq («Invitrogen») kit was used for the reverse transcription (RT) reaction. Nested reaction was performed using the same kit. The primers, RT and the nested reaction have been described by [12].

Results and discussion. Most of the seroepidemiological studies involving CVB infections during pregnancy are related to their association to T1D. The involvement of enterovirus infections as an environmental trigger of type 1 diabetes (T1D) and maternal infection during gravidity increases risk of T1D development and progress in children in age $0-14$ has been studied by $[13,14]$. Serological studies have shown the presence of anti-CVB IgM antibodies in pregnant women suggesting that coxsackievirus infection during pregnancy can be the cause of miscarriages and also linked to development of T1D in children whose mothers overcame infection during gravidity $[15,16]$.

Our aim was to analyze the circulation and current CVB infections in pregnant women. As observed in Table 1 serotype CVB4 was dominantly circulating in the studied population, followed by CVB3, CVA9, CVB5, CVB2 and CVB1. CVB6 prevalence is the least frequent. Furthermore as seen from Fig. 1: $25.35 \%$ of the studied cases had already encountered with five of chosen coxsackievirus serotypes, $1.84 \%$ against all of studied serotypes and $2.3 \%$ of gravid women did not have antibodies against any of observed serotype. Current infections was noted in 30 out of $217(13.82 \%)$ investigated pregnant women.

Transmission of virus from mother to suckling mice, primarily in later stages of gestation, has been considered to be possible as shown by [7]. We observed presence of RNA in all the dead fetuses in the experimentally infected dams in the $2^{\text {nd }}$ week of gestation. Table 2 shows the presence of enteroviral RNA 


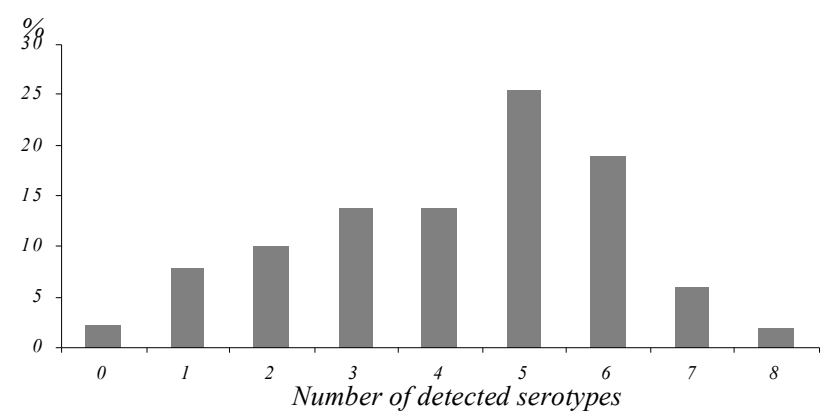

Fig. 1. Percentage of sera positive for antibodies against different coxsackievirus serotypes in the studied group: $x$ axis - number of detected serotypes; $y$ - percentage of studied sera $(n=217)$. Titers of anticoxsackievirus antibodies against: none of the serotypes $(2,3 \%) ; 1-$ $7.83 \%$; 2 - $10.14 \%$; 3 - $13.82 \%$; 4 - $13.82 \%$; $5-25.35 \%$; $6-$ $18.89 \% ; 7-5.99 \% ; 8-1.84 \%$

Table 2

The presence of viral RNA in the fetuses of a gravid mouse infected in the mid-gestation period of pregnancy

\begin{tabular}{c|c|c}
\hline Organ & Placenta and navelwort & Intestine \\
\hline+ total & $16 / 16$ & $9 / 11$ \\
\hline
\end{tabular}

$+/$ total $=$ number of RT-PCR positive fetus organs/total number of studied organs.

in the placenta and the navelwort of each of the unborn fetuses and in intestine of the most of dissected fetuses of the experimentally infected sick dam. Both were detected by RT-PCR.

The results of our experimental study suggest that the infection had an effect on the fetuses in the second week of gestation. Moreover we have shown that virus may be transferred on the progeny during intrauterinal development. This aspect should be studied further.

Conclusions. Serological study shows prevalence of coxsackievirus antibodies in gravid women in Slovak Republic. Our experimental infection study shows that the infection in the second week of gestation and may be a result of transfer of the virus from mother to fetus. We conclude that systematic follow up of CV infections and their consequences on the offspring, fetus and pregnancy should be closely studied. These studies infer the importance of a possibility of including coxsackieviruses in the screening of the viral infections during pregnancy.

Acknowledgements. Prof. J. M. Galama Nijmgen, the Netherlands (scientific discussions), Dr. A. Petrovicova (for advice in serology), Dr. D. Zelejnkova SMU Bratislava (veterinary care and advice), MZSR code: 2005/23-SZU-01, Norwegian financial support mechanism, Mechanism EEA and Slovak Government-Project SK0082.

Л. Марозова, М. Сойка, Я. Пресечтелова, Д. Стіпалова, М. Бадурова, М. Борсаньйова, С. Бопегамаге

Інфекції, спричинені вірусами Коксакі у вагітних, і паралельна експериментальні модель інфекції, яка демонструє можливі наслідки на перебіг вагітності

Резюме

Мета нашої роботи полягала, по-перше, у визначенні розповсюдженості антитіл проти вірусу Коксакі протягом вагітності (217 зразків сироватки крові перевіряли на наявність антитіл проти вирусу Коксакі (BК) B1-В6, A7 и A9) i, по-друге, у дослідженні передачі вірусу плоду під час васітності на модельній системі. Методи. Віруснейтралізувальний тест, ОТ-ПЛР. Результати. Проведено серологічне вивчення парних (мати-плід) зразків сироватки крові 217 вагітних жінок з різних районів Словацької Республіки на наявність антитіл проти вірусів Коксакі серотипів (ВКВ1-ВКВ6, CVA7 и ВКА9). Найпоширенішою інфекцією виявився вірус Коксакі В4 (ВКВ4), далі відмічені ВКВ3, ВКА7, ВКА9, ВКВ5, ВКВ2, ВКВ1, а інфікування В6 (ВКВ6) було найменшим. Інфекцію зареєстровано у 30 з 217 випадків (13,82\%). В експериментах на мишах протягом другого тижня вагітності ми спостерігали присутність ентеровірусної РНК у плаценті $і$ кишечнику мертвих плодів. Висновки. Антитіла проти вирусів Коксакі, знайдені у вагітних жінок, свідчать про розповсюдженість ичи вірусів у популяиії. Перебіг інфекції показано для 13,82\% проаналізованих випадків. Наявність вірусної РНК в органах плодів, які не народилися, за експериментальної інфекиії умишей вказує на можливість передачі вирусів Коксакі B4-E2 інфекції від матері плоду у період дородового розвитку.

Ключові слова: віруси Коксакі, вагітність.

Л. Марозова, М. Сойка, Я. Пресечтелова, Д. Стипалова, М. Бадурова, М. Борсаньйова, С. Бопегамаге

Инфекции, вызванные вирусами Коксаки у беременных женщин, и параллельная экспериментальная модель инфекции, показывающая возможные последствия на течение беременности

\section{Резюме}

Цель нашей работы состояла, во-первых, в определении распространенности антител против вируса Коксаки во время беременности (217 образцов сыворотки крови проверяли на наличие антител против вируса Коксаки (ВК) B1-В6, A7 и A9) и, во-вторых, в исследовании передачи вируса плоду во время беременности на модельной системе. Методы. Вируснейтрализуюший тест, ОТ-ПЦР. Результаты. Проведены серологическое изучение парных (мать-плод) образиов сыворотки крови 217 беременных женщин из различных районов Словацкой Республики на наличие антител против вирусов Коксаки серотипов (ВКВ1-ВКВ6, СVA7 и ВКА9). Наиболее распространенной инфекиией оказался вирус Коксаки В4 (ВКВ4), далее отмечены $B K B 3, B K A 7, B K A 9$, ВКВ5, ВКВ2, ВКВ1, а инфицирование В6 (ВКВ6) было наименьиим. Инфекция зарегистрирована в 30 из 217 случаев (13,82\%). В экспериментах на мымах в течение второй недели беременности мы наблюдали присутствие энтеровирусной РНК в плаченте и кишечнике мертвых плодов. 
Выводы. Антитела против вирусов Коксаки, обнаруженные у беременных женщин, свидетельствуют о распространенности этих вирусов в популяции. Протекание инфекции показано для 13,82\% проанализированных случаев. Наличие вирусной РНК в органах нерожденных плодов при экспериментальной инфекции у мышей указывает на возможность передачи вирусов Коксаки В4-Е2 инфекции от матери плоду в период дородового развития.

Ключевые слова: вирусы Коксаки, беременность.

\section{REFERENCES}

1. Georgopoulou A., Markoulatos P., Spyrou N., Vakalis N., Bei T. A., Vamvakopoulos $N$. C. High sequence divergence in the 5 non-coding region of reference Coxsackie $\mathrm{B}$ and ECHO viral strains and clinical isolates revealed by restriction fragment length polymorphism analysis // Mol. Cell. Probes.-2001.-15, N 6.-P. 317-327.

2. Oberste M. S., Maher K., Killpatrick D. R., Pallansch M. A. Molecular evolution of the human enteroviruses: correlation of serotype with VP1 sequence and application to picornavirus classification // J. Virol.-1999.-73, N 3.-P. 1941-1948.

3. Oberste M. S., Maher K., Flemister M. R., Marchetti G., Kilpatrick D. R., Pallansch $M$. A. Comparison of classic and molecular approaches for the identification of untypeable enteroviruses // J. Clin. Microbiol.-2000.-38, N 3.-P. 1170-1174.

4. Diedrich S., Schreier E. Aseptic meningitis in Germany associated with echovirus type 13 // BMC Infect. Dis.-2001.-1.-P. 14.

5. Siafakas N., Markoulatos P., Vlachos C., Stanway G., Tzanakaki G., Kourea-Kremastinou J. Molecular sub-grouping of enterovirus reference and wild type strains into distinct genetic clusters using a simple RFLP assay // Mol. Cell. Probes.-2003.-17, N 2-3.-P. 113-123.

6. Luppi P., Zanone M. M., Hyoty H., Rudert W. A., Haluszczak C., Alexander A. M., Bertera S., Becker D. Trucco M. Restricted TCR V beta gene expression and enterovirus infection in type I dia betes: a pilot study // Diabetologia.-2000.-43, N 12.P. 1484-1497.
7. Modlin J. F., Crumpacker C. S. Coxsackievirus B infection in pregnant mice and transplacental infection of the fetus // Infect. Immun.-1982.-37, N 1.-P. 222-226.

8. Palmer A. L., Rotbart H. A., Tyson R. W., Abzug M. J. Adverse effects of maternal enterovirus infection on the fetus and placenta // J. Infect. Dis.-1997.-176, N 6.-P. 1437-1444.

9. Dalldorf G., Gifford R. Susceptibility of gravid mice to Coxsackie virus infection // J. Exp. Med.-1954.-99, N 1.-P. 21-27.

10. Lansdown A. B. G. Influence of Coxsackie-virus B infections on fetal growth in mice // Teratology.-1976.-13, N 3.-P. 291-297.

11. Melnick J. L., Wenner H. A. Enteroviruses // Diagnostic procedures for viral and rickettsial infections / Eds E. H. Lennette, N. J. Smith (4 ${ }^{\text {th }}$ ed.).-New York: Amer. Publ. Health Assoc., 1969.-P. 529-602.

12. Bopegamage S., Kovacova J., Vargova A., Motusova J., Petrovicova A., Benkovicova M., Gomolcak P., Bakkers J., van Kuppeveld F., Melchers W. J., Galama J. M. Coxsackie B virus infection of mice: inoculation by the oral route protects the pancreas from damage, but not from infection // J. Gen. Virol.2005.-86, Pt 12.-P. 3271-3280.

13. Elfving M., Svensson J., Oikarinen S., Jonsson B., Olofsson P., Sundkvist G., Lindberg B., Lernmark A., Hyoty H., Ivarsson S.$A$. Maternal enterovirus infection during pregnancy as a risk factor in offspring diagnosed with type 1 diabetes between 15 and 30 years of age // Exp. Diabetes Res.-2008.-2008.-271958.

14. Hyoty H., Hiltunen M., Knip M., Laakkonen M., Vahasalo P., Karjalainen J., Koskela P., Roivainen M., Leinikki P., Hovi T. A prospective study of the role of Coxsackie B and other enterovirus infections in the pathogenesis of IDDM. Childhood diabetes in Finland (DiMe) study group // Diabetes.-1995.-44, N 6.-P. 652-657.

15. Axelsson C., Bondestam K., Frisk G., Bergstrom S., Diderholm $H$. Coxsackie B virus infections in women with miscarriage // J. Med. Virol.-1993.-39, N 4.-P. 282-285.

16. Dahlquist G., Frisk G., Ivarsson S. A., Svanberg L., Forsgren $M$., Diderholm $H$. Indications that maternal coxsackie B virus infection during pregnancy is a risk factor for childhood-onset IDDM // Diabetologia.-1995.-38, N 11.-P. 1371-1373.

UDC $612.63+578.835 .1$ Received 10.01.11 